\title{
THE ASSOCIATION BETWEEN POLYCYSTIC OVARIUM SYNDROME AND BODY MASS INDEX, ACNE VULGARIS, HIRSUTISM, IRREGULAR MENSTRUAL CYCLE
}

\author{
Uki Retno Budihastuti, Zarah Tin Cahyaningrum, \\ Widana Primaningtyas, Eric Edwin, Sri Sulistyowati
}

Department of Obstetrics and Gynecology, Dr. Moewardi Hospital, Surakarta

\begin{abstract}
Background: Polycystic Ovary Syndrome (PCOS) is a common endocrine disorder in women of reproductive age that may cause infertility. PCOS often receives little attention due to unrecognized risk factors. PCOS is often diagnosed when patients who want to have children are treated at the infertility clinic. The purpose of this study was to analyze the association between body mass index, acne vulgaris, hirsutism, menstrual cycle, and the risk of PCOS.

Subjects and Method: This was an analytic observational study with case control design conducted in RSUD Dr.Moewardi, Surakarta, Central Java. A sample of 60 patients was selected for this study by fixed disease sampling, consisting of 30 PCOS cases and 30 controls. The independent variables were: body mass index, acne vulgaris, hirsutism, and menstrual cycle. The dependent variable was the incidence of polycystic ovary syndrome. Data were collected by interview. Body mass index is measured by the weight scale and microtoise. The data were analyzed by a multiple logistic regression.

Results: High body mass index $(\mathrm{OR}=1.94 ; 95 \% \mathrm{CI}=1.01$ to $3.74 ; \mathrm{p}=0.047)$, hirsutism $(\mathrm{OR}=8.36 ; 95 \% \mathrm{CI}=2.07$ to $33.75 ; \mathrm{p}=0.003)$, acne vulgaris $(\mathrm{OR}=$ $2.451 ; 95 \% \mathrm{CI}=0.718$ to $8.367 ; \mathrm{p}=0.152)$, and irregular menstrual cycle $(\mathrm{OR}=$ $1.13 ; 95 \% \mathrm{CI}=0.66$ to $1.92 ; \mathrm{p}=0.661$ ) increased the risk of PCOS.

Conclusion: High body mass index, hirsutism, acne vulgaris, and irregular menstrual cycle increase the risk of PCOS.
\end{abstract}

Keywords: polycystic ovarium syndrome, body mass index, acne, hirsutism, menstrual cycle

\section{Corespondence:}

Uki Retno Budihastuti. Department of Obstetrics and Gynecology, Dr. Moewardi Hospital, Surakarta. Email: ukiretno@gmail.com. Mobile: +628122656140.

Mid-International Conference on Public Health, Best Western Premier Hotel, Solo, Indonesia, 18-19 April 2018 | 241 https://doi.org/10.26911/mid.icph.2018.05.03 